\title{
Strategi Penegakkan Disiplin Wali Nagari Terhadap Perangkat Nagari
}

\author{
Netrivianti \\ Universitas Ekasakti Padang
}

\begin{abstract}
A bstract
Base finding result at field points out that disciplined performing on 0 ffice's Wali Nagari Sawah Laweh Pasar Baru Pesisir Selatan was beginning get better which is with give authority according to task and function al ready being managed, giving well-being step-up on active clerk, arranging intern's meeting everyday jum' at with all peripheral and making severally performings supportive order be disciplined. Besides one constraint are faced which is: its reducing is ardour employee job because of low it science and its little wages of peripherals nagari. Effort thus that is done which is: giving construction and training, giving rebuke to is breach and given by welfare step-up. With that effort is expected all peripheral gets to work better with guidance and instruction already being given by $\mathrm{N}$ agari's Sponsor so materializes tall discipline.
\end{abstract}

\section{Pendahuluan}

Penyelenggaraan Pemerintahan Daerah sebagaimana diatur dalam Undang-undang Nomor 32 tahun 2004 yang sekarang telah direvisi menjadi Undang-undang Nomor 12 tahun 2008 ditujukan pada Kabupaten/ Kota. Dalam peraturan perundang-undangan tersebut secara eksplisit lebih ditekankan agar pemerintah daerah memberikan kontribusi yang nyata terhadap peningkatan pelayanan dan kesejahteraan masyarakat, pengembangan kehidupan demokrasi dan terciptanya hubungan yang serasi antara pusat dan daerah serta antar daerah.

Pemerintah daerah mempunyai tugas dan tanggung jawab yang tidak kalah pentingnya dengan pemerintah pusat, dalam usaha mewujudkan tujuan Nasional Negara Indonesia, sebagaimana tercantum dalam Pembukaan Undang-undang Dasar 1945 yang berbunyi : membentuk pemerintah Indonesia yang melindungi segenap bangsa Indonesia, dan ikut melaksanakan ketertiban dunia yang berdasarkan kemerdekaan, perdamaian abadi, dan keadilan sosial (Pembukaan undang-undang Dasar 1945 alinea ke4). Untuk mewujudkan tujuan Nasional itu harus ada kerjasama yang baik antara pemerintah pusat maupun pemerintah daerah juga masyarakat.

Biarpun program pemerintah terencana dengan baik tetapi masyarakat dan pegawai pemerintahan tidak mendukung maka tidak mungkin program-program pemerintah akan terlaksana dengan baik. Karena salah satu faktor penting yang sangat menentukan pencapaian tujuan pembangunan adalah faktor tenaga kerja atau faktor sumber daya manusia, karena bagaimanapun juga manusia merupakan asset yang berharga yang dimiliki oleh sebuah organisasi/ instansi.

Oleh karena peraturan sangat diperlukan untuk memberikan bimbingan dan petunjuk bagi perangkat dalam menciptakan keteraturan dan 
ketertiban termasuk pemerintah nagari, dengan keteraturan dan ketertiban dan semangat kerja, moral kerja, keefisienan dapat ditingkatkan, hal ini mendukung tercapainya tujuan penyelenggaraan Pemerintahan Nagari. Sanksi hukuman dalam meningkatkan disiplin diperlukan karena hukuman adalah untuk mendidik perangkat nagari supaya berprilaku mentaati peraturan sedangkan dalam memberikan hukuman Wali Nagari harus adil dan tegas.

Dalam kenyataannya berdasarkan observasi penulis dan laporan dari masyarakat di kantor Wali Nagari Sawah Laweh Pasar Baru Kecamatan Bayang Kabupaten Pesisir Selatan, penulis melihat masih ada para pegawai yang datang dan pergi tidak tepat waktu, sehingga banyaknya absensi kehadiran dengan berbagai macam alasan bahkan masih ada pelayanan administrasi yang lambat.

Rumusan Masalah

1. Bagaimana strategi wali nagari dalam penegakan disiplin terhadap Perangkat Nagari yang melanggar disiplin pada kantor Nagari Sawah Laweh Pasar Baru Kecamatan Bayang Kabupaten Pesisir Selatan?

2. Apa saja kendala yang dihadapi dalam strategi penegakan disiplin terhadap Perangkat Nagari yang melanggar disiplin pada kantor Wali Nagari Sawah Laweh Pasar Baru Kecamatan Bayang Kabupaten Pesisir Selatan?

3. Strategi apa saja yang dilakukan wali nagari untuk mengatasi kendala dalam penegakan disiplin terhadap Perangkat Nagari yang melanggar disiplin pada kantor Wali Nagari Sawah Lawah Pasar Baru Kecamatan Bayang Kabupaten Pesisir Selatan?

Tujuan Penelitian

1. Untuk mengetahui strategi Wali Nagari dalam penegakan disiplin terhadap Perangkat Nagari yang melanggar disiplin pada kantor Wali Nagari Sawah Laweh Pasar Baru Kecamatan Bayang Pesisir Selatan.

2. Untuk mengetahui kendala yang dihadapi dalam strategi penegakan disiplin Perangkat Nagari yang melanggar disiplin pada kantor Wali Nagari Sawah Laweh Pasar Baru Kecamatan Bayang Kabupaten Pesisir Selatan.

3. Untuk mengetahui strategi yang dilakukan dalam mengatasi kendala terhadap penegakan disiplin Perangkat Nagari yang melanggar disiplin pada kantor Wali Nagari Sawah Laweh Pasar Baru Kecamatan Bayang Kabupaten Pesisir Selatan.

II. Metedologi Penelitian

Metode Yang Digunakan.

Penelitian ini menggunakan pendekatan kualitatif dengan menggunakan metode deskriptif. Dimana peneliti mencoba menggambarkan 
semua gejala ataupun peristiwa dan fenomena secara apa adanya sesuai dengan data dan informasi yang telah diperoleh dari responden (sumber data), hal ini dilakukan dengan senantiasa mengacu pada pembahasan masalah penelitian yang sudah ditetapkan terlebih dahulu. Penelitian ini berusaha menggambarkan bagaimana upaya Wali Nagari dalam penegakan disiplin terhadap perangkatnya dalam menjalankan aktivitas. Sehingga tercipta penyelenggaraan Pemerintahan Nagari yang efektif dan efisien pada umumnya.

Populasi dan Sampel

Populasi dalam penelitian ini adalah seluruh perangkat nagari yang berada di Nagari Sawah Laweh Pasar Baru Kecamatan Bayang Kabupaten Pesisir Selatan. Sedangkan Informan Kunci (sampel) adalah orang yang betul-betul memahami permasalahan yang diteliti. Yang menjadi informan kunci dalam penelitian ini adalah orang yang terlibat langsung dalam pelaksanaan penegakan disiplin. yang terdiri dari 6 (enam) orang yaitu : Wali Nagari; Sekretaris Nagari; Kepala Urusan; tiga orang Wali Kampung.

\section{Analisa Data}

Teknik analisis data yang digunakan adalah teknik analisis data kualitatif, dengan melakukan analisis secara interaktif terhadap data yang telah diperoleh di lapangan selama proses penelitian berlangsung. Analisis data di lakukan dalam bentuk pengajuan pertanyaan-pertanyaan kepada unsur-unsur yang terkait agar proses pengumpulan data dapat di jamin keabsahannya. Dari hasil klasifikasi dan analisis di atas selanjutnya di lakukan pembahasaan.

\section{Hasil Penelitian dan Pembahasan}

Strategi Wali Nagari dalam penegakan disiplin

Kebijakan merupakan suatu langkah yang diambil oleh seseorang/ pimpinan dalam melaksanakan suatu pekerjaan, tanpa kebijakan karyawan akan merasa bebas karena tidak ada yang mengikat pegawai tersebut dalam melaksanakan pekerjaan sehingga ia akan bekerja dengan asal-asalan saja dan tidak memiliki kedisiplinan yang baik. Begitu pula dengan Wali Nagari selaku pimpinan dalam suatu Nagari harus memiliki kebijakan dalam menjalankan tugasnya yang harus dipatuhi oleh semua perangkat yang berada dikantor Wali Nagari tersebut.

Dari hasil wawancara penulis dengan Wali Nagari Sawah Laweh Pasar Baru Bapak Nasri. A. beliau mengatakan : "Dalam melakukan penegakan disiplin saya selaku Wali Nagari memberikan beberapa kebijakan terhadap Perangkat Nagari agar ia dapat bekerja dengan lebih baik diantaranya :

1. Memberikan wewenang sesuai dengan tugas dan fungsi yang telah diatur.

2. Memberikan peningkatan kesejahteraan pada pegawai yang giat dan beprestasi dalam bekerja.

3. Mengadakan pertemuan atau rapat intern setiap hari jumat. 
4. Membuat beberapa peraturan-peraturan guna untuk mendukung kelancaran pekerjaan. Seperti :
a. Berpakaian rapi dalam bekerja
b. Kepatuhan pegawai pada jam kerja
b. Penggunaan bahan-bahan perlengkapan kantor dengan hati-hati
c. Menghasilkan pekerjaan yang memuaskan
d. Mengikuti cara kerja yang telah ditentukan.

Dari hal diatas dapat disimpulkan bahwa dalam memimpin suatu Nagari, Wali Nagari juga harus memiliki kebijakan yang dapat diberikan kepada Perangkat Nagari agar pekerjaan yang diberikan dapat diselesaikan dengan baik, agar para pegawai dapat bekerja dengan penuh tanggung jawab dan memiliki kedisiplinan yang tinggi. Dapat dilihat dari hasil penelitian yang penulis lakukan dilapangan bahwa salah satu kebijakan Wali Nagari dalam strategi yang dilakukan Wali Nagari dalam penegakan disiplin terhadap Perangkat Nagari yaitu melalui peningkatan kesejahteraan bagi perangkat.

Dalam pelaksanaan disiplin Bapak Wali Nagari Nasri, A mengungkapkan bahwa : "Kehadiran dari para perangkat dalam 1 tahun terakhir ini sudah mulai membaik ini disebabkan karena saya sudah membuat beberapa peraturan yang telah disepakati bersama diantaranya masuk kerja jam 08.00wib dan pulang jam 16.00wib dengan mengisi absen yang telah disediakan dan juga karena perangkat sudah mulai menyadarinya dengan tugas yang ia miliki".

Dari pernyataan diatas dapat disimpulkan bahwa dalam membuat suatu kebijakan Wali Nagari terlebih dahulu meminta pesetujuan dari para perangkat agar nantinya tidak ada masalah dari para perangkat karena kebijakan itu dibuat atas persetujuan bersama untuk dipatuhi bersama. Dengan adanya hal ini juga akan meningkatkan hubungan baik antara Wali Nagari dengan Perangkat Nagari karena Wali Nagari tidak pernah membuat suatu peraturan tanpa merundingkan terlebih dahulu dengan perangkatnya. Yang mencakup dalam penegakan disiplin dikantor Wali Nagari Sawah Laweh Pasar Baru ini diantaranya : cara berpakaian, kehadiran, kepatuhan dalam melaksanakan tugas dan memberikan pelayanan yang baik terhadap masyarakat.

Kedisiplinan sangat penting bagi suatu organisasi, sebab dengan adanya disiplin diharapkan sebahagian besar peraturan dapat dijalankan oleh pegawai dan pekerjaan dapat dilakukan seefektif mungkin. Disiplin dalam bekerja menuntut adanya kesadaran yang tinggi untuk mematuhi aturan secara suka rela, tanpa ada perasaan tertekan.

Penegakan disiplin pada kantor Wali Nagari Sawah Laweh Pasar Baru Kecamatan Bayang sudah tergolong baik karena Wali Nagarinya selalu berupaya menjadikan Nagarinya menjadi Nagari yang berprestasi dan lebih baik, oleh karena itu dengan perangkat nagari haruslah :

1. Kepatuhan pegawai pada jam kerja

2. Berpakaian yang rapi ditempat kerja

3. Penggunaan bahan-bahan / perlengkapan kantor dengan hati-hati 
4. Menghasilkan pekerjaan yang memuaskan

5. Mengikuti cara untuk mendapatkan perangkat yang lebih baik yang mempunyai disiplin yang tinggi yaitu kerja yang ditentukan oleh organisasi.

Penegakan disiplin yang dilakukan oleh Wali Nagari adalah dengan memberikan beberapa kebijakan yang dapat menunjang penegakan disiplin diantaranya :

1. Memberikan wewenang sesuai dengan tugas dan fungsi yang telah diatur.

2. Memberikan peningkatan kesejahteraan pada pegawai yang giat dan beprestasi dalam bekerja.

3. Mengadakan pertemuan atau rapat intern setiap hari jumat.

4. Membuat beberapa peraturan-peraturan guna untuk mendukung kelancaran pekerjaan seperti :
a. Berpakaian rapi dalam bekerja
b. Kepatuhan pegawai pada jam kerja
b. Penggunaan bahan-bahan / perlengkapan kantor dengan hati-hati
c. Menghasilkan pekerjaan yang memuaskan
d. Mengikuti carakerja yang telah ditentukan.

Dilihat dari indikator diatas pelaksanaan disiplin pada Kantor Wali Nagari Sawah Laweh Pasar Baru Kecamatan Bayang sudah mulai meningkat seiring dengan kebijakan-kebijakan yang telah diberikan oleh Wali Nagari seperti :

1. Berpakaian rapi dalam bekerja

Pada kantor Wali Nagari Sawah Laweh Pasar Baru Kecamatan Bayang para pegawai sudah kelihatan rapi dan sopan dalam berpakaian. Pada hari Senin, Selasa dan Rabu perangkat memakai pakaian pemda lengkap dengan atributnya, hari Kamis berpakaian Olahraga dan pada hari Jum'at berpakaian muslim atau bebas yang penting sopan. Sehingga dapat dilihat keserasian diantara perangkat.

2. Kepatuhan pegawai pada jam kerja.

Yang dimaksud kepatuhan pegawai/ karyawan pada jam kerja adalah ketentuan waktu kerja, baik didalam maupun diluar kantor sesuai dengan wewenang batas waktu/jam yang telah ditentukan. Kepatuhan atau ketaatan pegawai pada atasan. Kepatuhan pegawai pada saat jam kerja pada kantor Wali Nagari Sawah Laweh Pasar Baru Kecamatan Bayang sudah mulai mengalami peningkatan. Setelah diberikan teguran dan dinasehati oleh Wali Nagari Pegawai sudah mulai menyadari akan pentingnya disiplin. Pegawai yang dulunya jarang betah berada dalam kantor sekarang sudah mulai betah seiring dengan timbulnya kesadaran mereka, walaupun masih ada sebagian dari pegawai yang datang terlambat. Yang mana waktu masuk jam 08.00 wib dan pulang jam 16.00 wib. 
3. Penggunaan bahan-bahan perlengkapan kantor dengan hati-hati.

Hal ini dimaksudkan memelihara sarana dan prasarana kantor sesuai dengan kepentingan instansi yaitu secara baik dan benar. Peralatan sangat penting artinya dalam melaksanakan tugas, karena semakin tinggi mutu peralatan dan tersedia dalam jumlah yang cukup akan memberi hasil kemudahan dan akan memberi kualitas pekerjaan yang baik serta dapat menghemat atau mengurangi tenaga yang kurang efisiensi dalam melaksanakan produktivitas dari tujuan yang hendak dicapai instansi. Dalam penggunaan perlengkapan kantor pegawai memang agak kesulitan terutama dalam pengoperasian computer ini disebabkan karena kurangnya skill yang dimiliki dan rasa ingin pandai pegawai juga kurang. Hal ini dipicu karena rendahnya tingkat pendidikan dari para pegawai.

4. Menghasilkan pekerjaan yan memuaskan.

Sejauh ini pekerjaan yang dihasilkan pegawai sudah mulai memuaskan karena seiring dengan kebijakan-kebijakan yang telah ditetapkan oleh Wali Nagari mendorong semangat kerja pegawai menjadi lebih baik dan mengahasilkan pekerjaan yang diinginkan.

5. Mengikuti cara kerja yang telah ditentukan.

Dalam melaksanakan tugasnya perangkat bekerja sesuai dengan tugas dan bidang yang telah diberikan kepadanya. Dan melaksanakan pekerjaan sesuai dengan cara kerja yang telah ditentukan. Dalam hal ini pegawai sudah mulai mengerti karena Wali Nagari selalu mengevaluasi setiap pekerjaan yang dianggap agak terkendala oleh pegawai.

Jadi dalam penelitian ini penegakan disiplin Perangkat Nagari Sawah Laweh Pasar Baru berdasarkan hasil wawancara dapat diketahui bahwa dalam melaksanakan pekerjaan bila mendapatkan arahan dan bimbingan dari Wali Nagari maka penegakan disiplin terhadap perangkat bisa meningkat. Penegakan disiplin pada kantor Wali Nagari Sawah Laweh Pasar Baru sangat penting agar dapat menghasilkan perangkat yang berkualitas dan berkompeten salah satu caranya adalah memberikan pembinaan, pelatihan dan memberikan pekerjaan sesuai dengan skillnya masing-masing.

Dan juga dengan adanya kebijakan yang dibuat oleh Wali Nagari bersama perangkatnya telah membuat Nagari Sawah Laweh Pasar Baru dalam 1 tahun terkahir ini menjadi Nagari yang lebih baik terutama dalam masalah kehadiran. Pada kantor Wali Nagari Sawah Laweh Pasar Baru sudah terlihat suasana kekeluargaan dan hubungan yang baik antara Perangkat Nagari dan Wali Nagari dan begitu juga antara sesama perangkat. $\mathrm{Hal}$ ini juga dirasakan oleh masyarakat yaitu dengan pelayanan yang diberikan oleh para perangkat Wali Nagari.

Kendala dalam penegakan disiplin

Dari hasil wawancara dengan bapak Nasri, A selaku Wali Nagari Sawah Laweh Pasar Baru, kendala yang dihadapi dalam penegakan disiplin adalah : "Terutama sekali dalam penegakan disiplin pegawai pada saat masuk kerja seperti sering datang terlambat dengan alasan pergi melihat air 
sawahnya terlebih dahulu sehingga terlambat kekantor, ini disebabkan karena sebagian besar dari masyarakat disini bermata pencaharian bertani"

Pernyataan diatas diperkuat oleh Kaur Kemasyarakatan yaitu Bapak Nafnaldi yaitu : "Dalam suatu kantor pastilah ada kendala yang dihadapi dalam melakukan penegakan disiplin namun kendala itu bisa diatasi dengan baik. Kendala yang sudah umum seperti kehadiran pegawai, waktu saya berurusan kekantor wali saya pergi jam 8 tapi belum ada pegawai satupun yang ada hanya bapak Wali Nagari padahal seharusnya masuk jam 8.00 masuk pukul 9 atau lewat dari jam 10"

Hasil wawancara dengan bapak Wali Nagari Sawah Laweh Pasar Baru Kecamatan Bayang dengan Bapak Nasri, A. bahwasanya kendala yang dihadapi dalam penegakan disiplin adalah : "Para perangkat masih kurang memahami tentang disiplin kepegawaian dan peraturan nagari sehingga mereka tidak bisa menjalankan Tugas dan fungsinya dengan baik hal ini juga disebabkan karena adanya sebagian dari pendidikan perangkat nagari ini yang rendah"

Dari pernyataan diatas dapat disimpulkan yaitu kendala berikutnya yang dihadapi dalam penegakan disiplin yaitu karena kurangnya pemahaman dari perangkat dalam memahami disiplin kepegawaian dan memahami Peraturan Nagari. ini juga karena faktor pendidikan yang rendah. Para perangkat harus diberi arahan dan bimbingan dalam menjalankan tugas oleh Wali Nagari karena dengan adanya bimbingan dan arahan yang diberikan kepada para perangkat maka para perangkat bisa mengerti dengan tugas yang akan dilaksanakannya.

Merujuk pada hasil wawancara diatas maka penulis dapat menyimpulkan bahwa kendala yang dihadapi Wali Nagari dalam melakukan penegakan disiplin terhadap perangkat nagari sawah laweh dapat diatasi dengan baik karena Wali Nagari mengatasinya dengan cara melakukan pendekatan dan pengawasan kepada perangkat-perangkat nagari. Dengan demikian Wali Nagari dapat mengamati secara langsung apa yang menjadi kesalahan dan diperbaiki secara langsung sehingga strategi yang dilakukan oleh Wali Nagari terlaksana secara langsung pada saat pekerjaan dilakukan oleh perangkat.

Strategi Wali Nagari dalam mengatasi kendala penegakan disiplin

Setelah mengetahui apa yang menjadi kendala Wali Nagari dalam Penegakan Disiplin terhadap Perangkat Nagari maka dalam hasil penelitian ini ada beberapa strategi yang dilakukan oleh Wali Nagari dalam Penegakan Disiplin, seperti penjelasan dan hasil wawancara penulis dengan Wali Nagari Sawah Laweh Pasar Baru kecamatan Bayang Kabupaten Pesisir Selatan Bapak Nasri A yaitu : "Kalau ada pegawai yang lalai atau tidak disiplin dalam melakukan pekerjaan bapak tidak segan-segan akan memberikan teguran/ peringatan secara langsung, setelah itu bapak akan melakukan pengawasan terhadap perangkat yang bermasalah namun bila tidak ada kemajuan dalam hasil kerjanya bapak akan memanggilnya keruangan bapak dan diberi binaan dan saran-saran" 
Pernyataan ini juga dikuatkan dengan hasil wawancara penulis dengan Sekretaris Nagari Ibuk Yasmainar menyatakan bahwa : “Dalam melaksanakan tugas kami dituntut untuk bekerja dengan baik dengan tingkat kedisiplinan yang tinggi karena jika kami tidak disiplin maka bapak Wali Nagari akan langsung memberi teguran kepada kami"

Dari hasil wawancara diatas tadi dapat ditarik kesimpulan bahwa Wali Nagari dalam dalam upaya mengatasi kendala yang dihadapi dalam penegakan disiplin terhadap perangkatnya dapat dilihat dari beberapa tindakan nyata seperti memberi teguran terhadap perangkat yang tidak disiplin dalam bekerja. Wali Nagari mengambil tindakan tersebut agar Nagari yang di pimpinnya dapat menjadi Nagari yang terbaik. Semua itu dapat tercapai dengan kerja sama yang baik antara Wali Nagari dan semua perangkatnya.

Disiplin merupakan ketaatan dan kepatuhan karyawan terhadap peraturan dan keputusan yang berlaku pada organisasi. Pegawai tidak mengelak dalam menjalankan tugas atau tanggung jawab yang diberikan dan mau menerima sanksi apabila ia melanggarnya dan apabila hal-hal tersebut dilaksanakan maka ketertiban pelaksanaan dan kelancaran tugas akan tercipta sehingga tujuan organisasi akan tercapai.

Dalam penelitian ini dapat dilihat upaya-upaya apa saja yang dilakukan Wali Nagari dalam mengatasi kendala terhadap strategi penegakan disiplin di kantor Wali Nagari Sawah Laweh Pasar Baru seperti halnya :

a. Memberikan pembinaan dan pelatihan kepada Perangkat Nagari.

Pengetahuan dan kemampuan mempengaruhi tingkat disiplin Perangkat Nagari, Wali Nagari dalam melaksanakan tugas. Untuk itu Wali Nagari harus memberikan kesempatan seluas-luasnya kepada Perangkat Wali Nagari untuk mengikuti pelatihan-pelatihan dan manghadiri pembinaanpembinaan yang berguna dalam pelaksanaan tugas. Dan juga berguna untuk menambah pengetahuan/ pengalaman dari perangkat.

b. Memberikan teguran kepada Perangkat Nagari yang melanggar disiplin Dalam penyelenggaraan tugas Pemerintahan Nagari, Perangkat Nagari yang lalai dan melanggar disiplin dalam menjalankan tugas-tugasnya sehingga pekerjaan yang dilakukan belum mencapai hasil yang optimal. Maka Wali Nagari akan menegur pegawai yang lalai dan tidak disiplin tersebut yang mana teguran itu berupa pemberian nasehat agar dia bisa bekerja dengan lebih baik.

c. Setidaknya setiap perangkat nagari merasa bertanggung jawab mengawasi dan melakukan pembinaan secara dini dilingkungan kerjanya mengenai kedisiplinan. Misalnya bilamana terdapat stafnya yang melanggar tindakan disiplin, setidaknya segera melakukan pendekatan untuk menanyakan permasalahan yang dihadapi dan permasalahan yang menyebabkan yang bersangkutan tidak disiplin.

d. Adanya peningkatan kesejahteraan dari nagari

Peningkatan kesejahteraan pegawai memang sangat didambakan oleh setiap pegawai terutama sekali yang berupa gaji. Ini digunakan untuk 
memacu semangat kerja dari para pegawai dengan adanya peningkatan kesejahteraan pegawai akan bekerja dengan lebih baik dan sungguhsungguh.

e. Setidaknya setiap perangkat nagari intropeksi dan merasa mensyukuri bahwa tidak semua orang bisa menjadi pegawai atau bekerja sebagai perangkat nagari.

Berdasarkan hasil penelitian yang telah penulis lakukan maka penulis dapat menyimpulkan secara singkat bahwa strategi yang dilakukan Wali Nagari dalam mengatasi kendala dalam melakukakan penegakan disiplin adalah :

1. Memberi teguran.

2. Melakukan evaluasi kerja terhadap kerja perangkat nagari.

3. Adanya peningkatan kesejahteraan dari Nagari.

4. Memberikan pembinaan dan pelatihan guna untuk mengatasi kendala dalam penegakan disiplin pada perangkat nagari.

Dengan kerja keras dari Wali Nagari tersebut dalam melakukan Penegakan Disiplin terhadap perangkat nagari dan keinginan untuk menjadi yang lebih baik dari para perangkatnya.

IV. Kesimpulan

Berdasarkan hasil penelitian yang telah dijelaskan dibagian terdahulu tentang Strategi Wali Nagari dalam Penegakan Disiplin terhadap Perangkat Nagari Sawah Laweh Pasar Baru Kecamatan Bayang Kabupaten Pesisir Selatan maka dapat ditarik kesimpulan :

1. Kebijakan dan langkah-langkah yang dilakukan Wali Nagari dalam penegakan disiplin terhadap Perangkat Nagari yang melanggar disiplin pada kantor Wali Nagari Sawah Laweh Pasar Baru adalah : Memberikan wewenang sesuai dengan tugas dan fungsi yang telah diatur, memberikan peningkatan kesejahteraan pada pegawai yang giat dan beprestasi dalam bekerja, mengadakan pertemuan atau rapat intern setiap hari jumat, membuat beberapa peraturan-peraturan guna untuk mendukung kelancaran pekerjaan seperti :

a. Berpakaian rapi dalam bekerja.

b. Kepatuhan pegawai pada jam kerja.

c. Penggunaan bahan-bahan / perlengkapan kantor dengan hati-hati.

d. Menghasilkan pekerjaan yang memuaskan.

e. Mengikuti carakerja yang telah ditentukan.

2. Kendala yang dihadapi Wali Nagari dalam Penegakan Disiplin terhadap Perangkat Nagari yang melanggar disiplin pada kantor Wali Nagari Sawah Laweh Pasar Baru yaitu dilihat dari Kendala yang terjadi yaitu dalam diri perangkat sendiri, hal ini terjadi karena kurangnya rasa semangat kerja dalam diri perangkat sehingga pekerjaan yang dilakukan tidak terselesaikan dengan baik, banyak pegawai yang malas dalam menyelesaikan pekerjaan. faktor yang menyebabkan kurangnya semangat kerja pegawai yaitu : kecilnya gaji dan kurangnya pengetahuan yang dimiliki oleh pegawai adanya kegiatan yang dilakukan oleh pegawai selain dikantor seperti pegawai yang juga bermata pencaharian bertani 
sebelum berangkat kekantor pegawai tersebut terlebih dahulu pergi kesawah untuk mengairi sawah dan ada juga yang mengantarkan anak sekolah dengan alasan itu pegawai sering masuk terlambat. Namun dengan kebijakan-kebijakan yang diberikan Wali Nagari sudah terlihat perubahan terutama dalam tingkat kedisiplinan dan cara kerjanya.

3. Strategi yang dilakukan Wali Nagari untuk mengatasi kendala dalam penegakan disiplin terhadap Perangkat Nagari yang, melanggar disiplin pada kantor Wali Nagari Sawah Laweh Pasar Baru seperti :

a. Memberikan pembinaan dan pelatihan kepada Perangkat Nagari.

Pengetahuan dan kemampuan mempengaruhi tingkat disiplin Perangkat Nagari dalam melaksanakan tugas. Untuk itu Wali Nagari harus memberikan kesempatan seluas-luasnya kepada Perangkat Nagari untuk mengikuti pelatihan-pelatihan dan manghadiri pembinaan-pembinaan yang berguna dalam pelaksanaan tugas.

b. Memberikan teguran kepada Perangkat Nagari yang melanggar disiplin.

Dalam penyelenggaraan tugas Pemerintahan Nagari, Perangkat Nagari yang lalai dan melanggar disiplin dalam menjalankan tugastugasnya sehingga pekerjaan yang dilakukan belum mencapai hasil yang optimal. Maka Wali Nagari akan menegur pegawai yang lalai dan tidak disiplin tersebut.

c. Adanya peningkatan kesejahteraan dari nagari

Ini digunakan untuk memacu semangat kerja dari para pegawai dengan adanya peningkatan kesejahteraan pegawai akan bekerja dengan lebih baik dan sungguh-sungguh

Saran

Adapun saran yang dapat diberikan terhadap Stategi Wali Nagari dalam Penegakan Disiplin Terhadap Perangkat Nagari Sawah Laweh Pasar Baru Kecamatan Bayang Kabupaten Pesisir Selatan adalah :

1. Kebijakan dan langkah-langkah yang dilakukan Wali Nagari dalam penegakan disiplin terhadap Perangkat Nagari yang melanggar disiplin pada kantor Wali Nagari Pasar Baru dengan kebijakan yang telah ditetapkan sebaiknya harus ada sanksi yang lebih mengikat sehingga para pegawai menjadi takut untuk melakukan pelanggaran disiplin.

2. Kendala yang dihadapi Wali Nagari dalam penegakan disiplin terhadap Perangkat Nagari yang melanggar disiplin pada kantor Wali Nagari Sawah Laweh Pasar Baru yaitu diharapkan kepada pegawai lebih meningkatkan kemampuan pegawai dalam menggunakan sarana dan prasarana dalam kantor agar pekerjaan yang dilakukan dapat diselesaikan secara efektif dan efisien.

3. Strategi yang dilakukan Wali Nagari untuk mengatasi kendala, Dalam penegakan disiplin terhadap Perangkat Nagari yang melanggar disiplin pada kantor Wali Nagari Sawah Laweh Pasar Baru seperti : sudah terlihat dampaknya dan sebaiknya Wali Nagari dan para perangkatnya tetap meningkatkan cara kerjanya agar terus menjadi Nagari yang berprestasi. 


\section{Daftar Kepustakaan}

Abdurrahmat. Fathoni.2006. Organisasi \& Manajnemen Sumber Daya Manusia. Jakarta: PT.Asri Mahasatya.

Alex.S.Nitisemito.1991. Manajemen Personalia,Manajemen Sumber Daya Manusia. Jakarta: Bumi A ksara.

Alfred R. Lateiner dan IE. Levine, 1971, Teknik Memimpin Pegawai dan Pekerja, Jakarta : Jaya Sakti.

Anshar, S. (2019). PERAN NINIK MAMAK DALAM PENINGKATAN PEMUNGUTAN PAJAK BUMI DAN BANGUNAN (PBB) DI NAGARI LANSANO TARATAK KECAMATAN SUTERA KABUPATEN PESISIR SELATAN.

Edwin. B.Flippo.1997. Manajemen Personalia, Jakarta : PT.Gelora Aksara Pratama.

Imam. Soedjono. 1997. Teknik Memimpin Pegawai dan Pekerja.Jakarta : Aksara Baru.

Malayu. Hasibuan, 2000. Manajemen Sumber Daya Manusia. Edisi revisi, Jakarta : Ghalia Aksara

Mulia, R. A., \& Fitri, A. (2019). PENGARUH KARAKTERISTIK KEPEMIMPINAN TERHADAP MOTIVASI KERJA KARYAWAN DI PT. MEGA MEDICA PHARMACEUTICALS.

H. Nainggolan. 1988. Pembinaan Pegawai Negeri Sipil. Jakarta : PT. Pertja.

Prijodarminto, 1991. Disiplin Kiat Menuju Sukses, Jakarta : Pradya Paramita.

Saydam. Gozali 1996. Manajemen Sumber Daya Manusia. Jakarta: PT.Gunung Agung.

Suad. Husnan. 1993. Manajemen Personalia. Yogyakarta : BPFE.

Veithzal. Rivai. 2004. Manajemen Personalia dan Sumber Daya Manusia Untuk Perusahaan. Jakarta: PT.Raja Grapindo Persada.

Winardi. 2001. Motivasi dan Pemotivasian dalam Manajemen, Jakarta: PT.Raja Grafindo

Moleong. J. Lexy.2011. Metodologi Penelitian Kualitatif. Bandung : PT. Remaja Rosda Karya.

Peraturan Daerah Provinsi Sumatera Barat No. 2 tahun 2007 tentang Pokokpokok Pemerintahan Nagari. 2007. Padang : Pemerintahan Provinsi Sumatera Barat. 